\title{
The first seven months of an infant of Alouatta guariba (Humboldt) (Primates, Atelidae): interactions and the development of behavioral patterns ${ }^{1}$
}

\author{
João M. D. Miranda ${ }^{2}$, Lucas M. Aguiar ${ }^{2}$, Gabriela Ludwig ${ }^{2}$, Rodrigo F. Moro-Rios ${ }^{2,3} \&$ Fernando C. Passos ${ }^{2}$ \\ ${ }^{1}$ Contribution number 1564 of the Departamento de Zoologia, Universidade Federal do Paraná. \\ ${ }^{2}$ Laboratório de Biodiversidade, Conservação e Ecologia de Animais Silvestres, Departamento de Zoologia, Universidade \\ Federal do Paraná. Caixa Postal 19020,81531-980 Curitiba, Paraná, Brasil. E-mail: guaribajoao@yahoo.com.br; \\ lucasmoraes@ufpr.br; gabiludwig@ufpr.br; rtkd@pop.com.br; fpassos@ufpr.br. \\ ${ }^{3}$ Bolsista CNPq/PIBIC.
}

\begin{abstract}
The development of the interactions of an infant primate with its mother and the other members of its social group plays a special role in the ethology and demography of the species, with consequences for their survive and their conservation. The objective of the present study is to investigate the development of an infant of Alouatta guariba (Humboldt, 1812) in the wild, its behavior and interactions during its first seven months of age, in a remnant of Araucaria Pine Forest in Paraná State, Brazil. Using the method of instantaneous scanning with 5 min intervals, a total of 46 hours and 15 minutes of direct observation (555 individual records) showed that the infant behavioral patterns during its first four months were characterized by high dependency, which decreased progressively until the appearance of typically juvenile behaviors during the remaining 3 months. The first records of feeding on solid food, tail functionality and allomaternal care were also recorded and discussed. This work contributes to an understanding of the ontogenetic development of a poorly known aspect of this species, and thus for a more understanding of the genus Alouatta Lacépède, 1799.
\end{abstract}

KEY WORDS. Infancy, ontogenetic development, parental care, social behavior.

RESUMO. Os sete primeiros meses de um infante de Alouatta guariba (Humboldt) (Primates, Atelidae): interações e desenvolvimento dos padrões comportamentais. $O$ desenvolvimento das interações do infante primata com a mãe e demais membros do grupo social tem importância na etologia e na demografia da espécie, apresentando profundas consequiências para sua sobrevivência e portanto, na conservação da espécie. O objetivo deste trabalho foi estudar o desenvolvimento de um infante de Alouatta guariba (Humboldt, 1812) em vida livre, seu comportamento e interações durante os sete primeiros meses de vida, em um remanescente de Floresta Ombrófila Mista, Estado do Paraná, Brasil. Através do método de varredura instantânea com intervalo de cinco minutos, um total de 46 horas e 15 minutos de observações diretas (555 registros individuais) mostraram que os padrões comportamentais do infante foram de alta dependência nos primeiros quatro meses, diminuindo progressivamente até o aparecimento dos comportamentos típicos de indivíduos juvenis durante os últimos três meses. Os primeiros registros de alimentação sólida, funcionalidade da cauda e registros de cuidados alomaternais também foram tomados e discutidos, contribuindo para o entendimento do desenvolvimento deste infante.

PALAVRAS CHAVE. Comportamento social, cuidado parental, desenvolvimento ontogenético, infância.

The principal, longest and most intense social link among primates is that between mother and offspring (FEDIGAN 1982, STRIER 2003). Contrary to other mammal orders, the survivorship of the infant primate is completely dependent on the care provided by members of its social group, particularly through maternal care. Therefore, it is crucial that mothers recognize their infants as their own offspring, and that they are motivated to provide maternal care (MAESTRIPIERI 2001). By observ- ing and interacting with her, the infant learns what to eat and what to fear, who to dominate and who to submit to, where to walk, sleep and drink (FEDIGAN 1982). In addition, the mother might represent a source of thermoregulation, grooming and defense against predators and other aggressors (STRIER 2003). Over time, the infant progressively becomes independent of her, acquiring important biological and psychological advantages, such as the familiarity with its physical and social mi- 
lieu. At the same time, this enables the mother additional chances for mating and reproducing, providing simultaneous increase in several facets of her inclusive fitness (RHEINGOLD \& ECKERMAN 1970).

Starting with the pioneer work of HarLow \& ZimmermanN (1959) on the affective links of infants of Macaca Lacépède, 1799 , several studies in the field and in captivity, have addressed the behavioral interactions between mother and offspring in non-human primates, both in the Old and in the New World (Rheingold \& ECKERMan 1970). Therefore, special emphasis on the study of this behavior are of crucial importance to understand the biology, ethology and demography of these animals, given that, once the success of this ontogenetic phase is guaranteed, there is increased chance of recruitment and thus of group and population growth.

In addition to maternal care, paternal investments and other forms of allomaternal care might be present in several species depending on their social systems. The quality and quantity of allomaternal interactions with infants would depend on the degree of kinship: when group members are closely related (1), the interactions of this kind could be more cooperative; however, when group members are not closely related (2), expected interactions could be of a more competitive nature (CLARKE et al. 1998).

In the case of neotropical primates, polygynic systems such as the one found in Cebus Erxleben, 1777 and monogamic families such as those found in callitrichids might produce the allomaternal interactions expected under (1) (see SÁnchez et al. 1999, Schradin \& Anzenberger 2001, Tardiff et al. 2002). On the other hand, in the genus Alouatta Lacépède, 1799 the social system is shaped by male and female migrations, generating lower relatedness, causing interactions to be expected to correspond to (2). However, few studies have addressed directly those interactions in species of the genus Alouatta. In general, such descriptions are concentrated on the two most studied species: A. seniculus (Linnaeus, 1766) and A. palliata (Gray, 1848) (LyALL 1996 and see reviews in Neville et al. 1988, Defler 2004), in addition to the works by CAlegaro-Marques \& Bicca-Marques (1993a) on Alouatta caraya (Humboldt, 1812).

With regard to the investigation of infancy of individuals of $A$. guariba (Humboldt, 1812), a species endemic to the South and Southeast portions of the Brazilian Atlantic Rainforest, no study has hitherto given priority to this theme in such studies. Given that it is still unclear how the information based on the three well known species described above can be extrapolated to the rest of the genus Alouatta (Rumiz 1990), studies on the behavioral mother-offspring interaction in $A$. guariba and other species are necessary to understand this genus in a more holistic way. This information might also contribute vital information for the conservation of this species, which is currently enlisted vulnerable to extinction in several sites along its geographical range (IвAma 2003, Marques 2003, Margarido \& Braga 2004).
The goal of the present study was to investigate the development of an infant of Alouatta guariba, subspecies $A . g$. clamitans Cabrera, 1940 in the wild, as well as its maternal and allomaternal relationships during the first seven months of its life, in a remnant of Araucaria Pine forest in Southern Brazil.

\section{MATERIAL AND METHODS}

The present study was conducted in a 700 ha remnant of Araucaria Pine Forest located in the Bugre district, Municipality of Balsa Nova, State of Paraná (25 $29^{\prime} 52^{\prime \prime} \mathrm{W}$ and $\left.49^{\circ} 39^{\prime} 24^{\prime \prime} \mathrm{S}\right)$. The climate in the region is of the $C f b$ type according to the Köpen classification (IAPAR 1978), with an average annual temperature of $18^{\circ} \mathrm{C}$ and average annual rainfall of $1600 \mathrm{~mm}$ (data obtained from the Meteorological Station of the Municipality of Lapa). Being composed mostly of altered primary forest, this remnant experienced a pressure of selective tree cutting over its history. Currently, this region is conserved as part of the State Area of Environmental Protection of the Devonian Scarp.

This study was planned during the monitoring of one of the groups of $A$. guariba that have been followed in the study area since 2002 (Miranda \& Passos 2004, 2005). Beginning on the birth of the infant in question (in the week between 11 and 18 April 2004), it was possible to study its development and its interactions in the wild. In April of 2004, time of the birth of the infant, the group was composed by an adult male, two adult females, a sub-adult male, a juvenile I and a juvenile II (age/sex classification sensu Mendes 1989). During the next seven months, this infant and its mother were the main foci of observation, being followed during data collection with respect to their interactions and behavioral patterns. These data were obtained using the method of instantaneous scann sampling with records every five minutes (Altmann 1974).

The infant was born in the Fall of 2004, more precisely in the week between 11 and 18 of April, when it was first seen and, together with its mother and the other members of the group, started to be followed by the observers. The mother and the infant were followed during the first seven months of the infant's life, totaling 46 hours and 15 minutes of direct observations, and 555 individual records.

\section{RESULTS}

During the first days of its life, the infant was positioned $100 \%$ of the time ventrally of its mother, being active only during nursing (Fig. 1). At the end of the first month of life, the use of this position gradually started to decrease and the dorsum of the mother was used more frequently: $60 \%$ in the ventral position and $30 \%$ in the dorsal position. Also following a progressive manner, peaking during its fifth month of age, the infant began to behave more independently, with exploratory behaviors and movements away from its mother (Fig. 1), which was observed, in some occasions, even to reject the infant and to prevent it to position itself on her dorsum. 


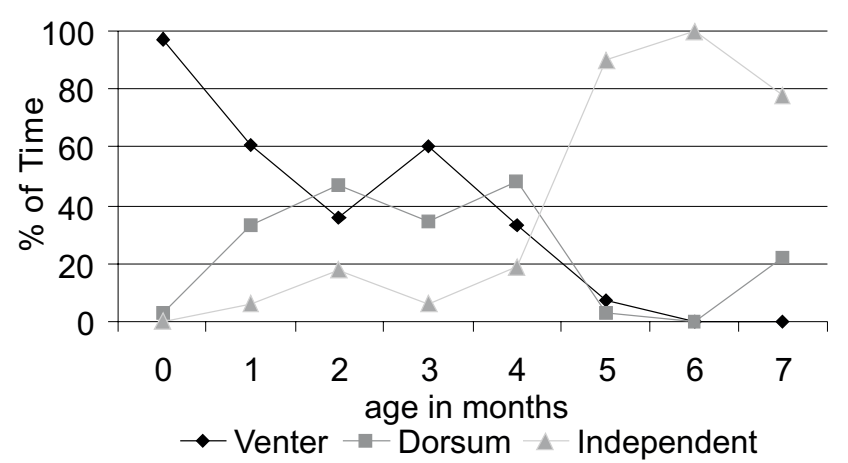

Figure 1. Position of the infant in relation to the body of the mother. $\mathrm{N}=555$ records.

Already during its first month the infant began to descend from the dorsum of its mother, although always remaining close to her. In the next month, the time spent by the infant away from its mother's dorsum gradually increased and, during the month of September, at the age of five months, it spent $90 \%$ of its time with no contact with her, although occasionally climbing her back, culminating in a high level of independence in the last months of the study.

The behavioral patterns of the infant during its first four months were closely linked and dependent on its mother, yet starting on the fifth month, this relationship weakened and other activities such as rest, feeding on solid food and movement began to dominate its daily behaviors, which began to appear progressively more like the independent juvenile individuals (Fig. 2).

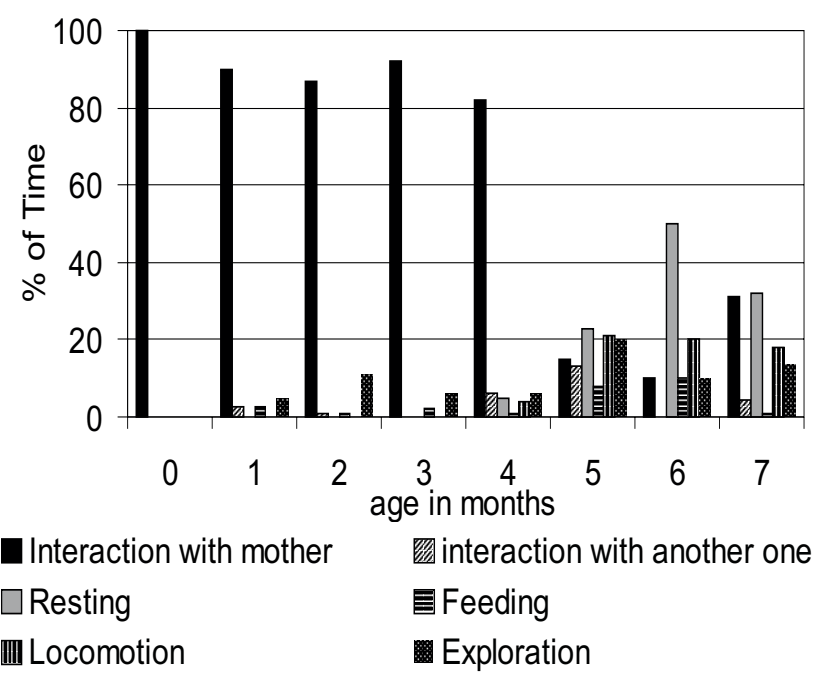

Figure 2. Development of the activity pattern of the infant along its first seven months of life. $\mathrm{N}=555$ records.
During the month of April, right before completing one month of age, no form of allomaternal care was observed. Starting in May, the infant initiated exploratory behaviors, particularly on its mother's body. In the same month, other individuals were recorded carrying the infant on their dorsum: a juvenile male II, a sub-adult male and an adult female, in that order of occurrence. Male individuals were identified as their brothers, however its relatedness with the other adult female is unknown. In the beginning of the same month, there was the first record of consumption of solid food by the infant: new leaves of the "bracatinga" - Mimosa scabrella Benth., with the second and third records occurring in the beginning of June and July (second and third months of age): a fruit and a floral bud, respectively. In the middle of May, the first prehensile use of the tail was observed, when the infant was in a hanging posture during exploratory activities near its mother.

In June, at age of two months, the infant used the opportunity when the mother descended to a water puddle beside a creek to drink water, and, while still being on its mother's back, leaned downward to drink directly with its mouth, supporting its body with one of its hands on the ground. In August, when it was close to four months of age, the infant began to participate in plays with its juvenile brothers that could be classified as fights and chases. Starting in the same month, plays became frequent during resting periods of the adult individuals.

In September, at the age of five months, its activities started to become more independent of its mother, including movement by itself. The animal began a transition phase and in November, at the age of seven months, when its behaviors became increasingly similar to juvenile I individuals.

\section{DISCUSSION}

The results obtained in the present study with respect to the age variation in the position of the infant in the body of its mother are similar to what is observed in other species of the genus Alouatta. In general, there is a gradual shift from the venter to the dorsum of the mother over the course of two to four weeks in Alouatta palliata (CARPENTER 1934, Altmann 1959, Lyall 1996, Defler 2004), six to ten weeks in A. senilicus (MaCK 1979, Neville et al. 1988, Defler 2004), and even later as in the case of $A$. belzebul (Linnaeus, 1766), where an infant was carried on the venter of the mother for three months and then on her back for five more months (Bonvicino 1989).

Although MaCK (1979) and Clarke (1990) indicate that the consumption of solid food by infants occurs from the second month of age on, the present study observed this behavior when the infant was only one month of age, as observed by Lyall (1996) on A. palliata. According to MaCK (1979), Neville et al. (1988) and Defler (2004), the tail of an Alouatta infant is only functional when it is one and a half to two months of age. However, the present study indicates that the studied infant showed tail functionality by supporting its own weight when it was only one-month-old, according with LyaLL (1996) 
study. These small variations in infant developmental period can occur among species, among sexes, environments, individuals peculiarties and even depending on the time of the year when the infant was born (FEDIGAN 1982, Clarke 1990, Calegaro-Marques \& Bicca-Marques 1993b, Strier 2003, Kowalewski \& ZUNINO 2004).

In September, the five-month-old infant started to display instances of movement, feeding and participation in plays in a way similar to the patterns observed in juvenile animals (Bonvicino 1989, Mendes 1989, Chiarello 1993, Bicca-Marques \& Calegaro-Marques 1994). According to Mack (1979), these behaviors can represent the beginning of their independence and a shift in their age class. As suggested by MeNDEs (1989) and used by Miranda \& PASSOS (2005), the focal animal of this study would be in a transition phase between an infant and a juvenile I.

The present study recorded few instances of allomaternal care, a result consistent with a social system shaped by male and female migrations and the ensuing decrease in relatedness among members of the group (see Clarke et al. 1998). However, allomaternal care was common in other Alouatta species such as A. palliata (Clarke et al. 1998), A. senilicus (MACK 1979) and A. caraya (Calegaro-Marques \& Bicca-Marques 1993a, Bravo $\&$ Sallenave 2003), particularly by other females of the group. However, these three species form large groups (Neville et al. 1988, Rumiz 1990, Treves 2001, Defler 2004) in contrast to what is observed in A. guariba (Silva JR. 1981, Neville et al. 1988, Mendes 1989, Miranda \& Passos 2005). In the present study, males (their brothers) were the most involved in interactions with the infant, both in carrying and in plays. This was possibly a consequence of their degree of relatedness of those individuals with the infant, as well as the scarcity of females in the group (see Material and Methods).

Consistent to what was previously pointed out by Rumiz (1990), the present study indicates that data available for some species often cannot be extrapolated to others, and that additional field information on parental care and infant development should be obtained to fully comprehend this topic in the genus Alouatta. On the other hand, information obtained here already contribute to a better understanding on infants of $A . g$. clamitans, its social interactions and its behaviors.

\section{AKNOWLEDGEMENTS}

We thanks to CNPq for studies support to J.M.D. Miranda, L.M. Aguiar, G. Ludwig and R.F. Moro-Rios.

\section{REFERENCES}

Altmann, S.A. 1959. Field observations on a howling monkey society. Journal of Mammalogy, Lawrence, 40 (3): 317-330.

Altmann, J. 1974. Observational study of behavior: sampling methods. Behaviour, Leiden, 40: 227-267.

Bicca-Marques, J.C. \& C. Calegaro-Marques. 1994. Activity budget and diet of Alouatta caraya: an age-sex analysis. Folia
Primatologica, Basel, 63 (4): 216-220.

Bonvicino, C.R. 1989. Ecologia e comportamento de Alouatta belzebul (Primates: Cebidae) na Mata Atlântica. Revista Nordestina de Biologia, João Pessoa, 6 (2): 149-179.

Bravo, S.P \& A. Sallenave. 2003. Foraging behavior and activity patterns of Alouatta caraya in the northeastern Argentinean Flooded Forest. International Journal of Primatology, Chicago, 24 (4): 825-846.

Calegaro-Marques, C. \& J.C. Bicca-Marques. 1993a. Allomaternal care in the black howler monkey (Alouatta caraya). Folia Primatologica, Basel, 61: 104-109.

Calegaro-Marques, C. \& J.C. Bicca-Marques. 1993b. Reprodução de Alouatta caraya Humboldt, 1812 (Primates, Cebidae), p. 51-66. In: M.E. Yамамото \& M.B.C. SouZA (Eds). A Primatologia no Brasil - 4. Salvador, FNMA, UFRN, Sociedade Brasileira de Primatologia, 327p.

Carpenter, C.R. 1934. A field study of behavior of howling monkeys. Comparative Psychology Monography, Fort Worth, 10: 1-68.

Chiarello, A.G. 1993. Activity pattern of the brown howler monkey Alouatta fusca, Geoffroy 1812, in a forest fragment of southeastern Brazil. Primates, Tóquio, 34 (3): 173-175.

Clarke, M.R. 1990. Behavioral development and socialization of infants in a free-ranging group of Howling Monkeys (Alouatta palliata). Folia Primatologica, Basel, 54: 1-15.

Clarke, M.R.; K.E. Glander \& E.L. ZuCKer. 1998. Infant-nonmother interactions of free-ranging Mantled Howlers (Alouatta palliata) in Costa Rica. International Journal of Primatology, Chicago, 19 (3): 451-472.

Defler, T.R. 2004. Primates of Colombia. Bogotá, Conservation International, 550p.

Fedigan, L.M. 1982. Primate Paradigms: sex roles and social bonds. Montreal, Eden Press, 386p.

Harlow, H.F. \& R.R. Zimmermann. 1959. Affectional responses in the infant monkey. Science, Washington, 130 (3373): 421432.

IAPAR. 1978. Cartas climáticas básicas do estado do Paraná. Londrina, Instituto Agronômico do Paraná, 38p.

Iвама. 2003. Lista das espécies da fauna brasileira ameaçadas de extinção. Brasília, Ibama, 19p.

Kowalewski, M. \& G.E. Zunino. 2004. Birth seazonality in Alouatta caraya in northern Argentina. International Journal of Primatology, Chicago, 25 (2): 383-400.

LYALL, Z.S. 1996. The early development of behavior and independence in Howler Monkeys, Alouatta palliata mexicana. Neotropical Primates, Washington, 4 (1): 4-8.

MAск, D. 1979. Growth and development of infant red howling monkeys (Alouatta seniculus) in a free ranging population, p. 127-136. In: J.F. EISENBERG, (Ed.). Vertebrate ecology in the Northern Neotropics. Washington, Smithsonian Institution Press, 271p.

Maestripieri, D. 2001. Is there mother-infant bonding in Primates? Developmental Review, Arlington, 21: 93-120. 
Margarido, T. C. \& F. G. Braga. 2004. Mamíferos, p. 27-142. In: S. B. Мiкich \& R. S. BéRnils (Eds). Livro vermelho da fauna ameaçada no estado do Paraná. Curitiba, Governo do Estado do Paraná, IAP, SEMA, 763p.

Marques, A.A.B. 2003. Primates, p. 499-506. In: C.S. Fontana; G.A. BENCKE \& R.E. ReIs. (Eds). Livro vermelho da fauna ameaçada de extinção do Rio Grande do Sul. Porto Alegre, EDIPUCRS, 632p.

Mendes, S.L. 1989. Estudo ecológico de Alouatta fusca (Primates: Cebidae) na Estação Biológica de Caratinga, MG. Revista Nordestina de Biologia, João Pessoa, 6 (2): 71-104.

Miranda, J.M.D. \& F.C. Passos. 2004. Hábito alimentar de Alouatta guariba (Humboldt) (Primates, Atelidae) em Floresta de Araucária, Paraná, Brasil. Revista Brasileira de Zoologia, Curitiba, 21 (4): 821-826.

Miranda, J.M.D. \& F.C. Passos. 2005. Composição e dinâmica de grupos de Alouatta guariba clamitans Cabrera (Primates, Atelidae) em um remanescente de Floresta Ombrófila Mista, no Estado do Paraná, Brasil. Revista Brasileira de Zoologia, Curitiba, 22 (1): 99-106.

Neville, M.K.; K.E. Glander; F. Braza \& A.B. Rylands. 1988. The Howling Monkeys, Genus Alouatta, p. 349-453. In: R.A. Mittermeier; A.B. Rylands; A. Coimbra-Filho \& G.A.B. Fonseca (Eds). Ecology and Behavior of Neotropical Primates. Washington, World Wildlife Fund, vol. 2, 610p.

Rheingold, H.L. \& C.O. Eckerman. 1970. The infant separates himself from his mother. Science, Washington, 168 (3927):
78-83.

Rumiz, D.I. 1990. Alouatta caraya: Population density and demography in Northern Argentina. American Journal of Primatology, Calgary, 21: 279-294.

Sánchez, S.; F. Peláez; C. Gil-Burmann \& W. Kaumanns. 1999. Costs of infant-carrying in the Cotton-Top Tamarin (Saguinus oedipus). American Journal of Primatology, Calgary, 48: 99-111.

Schradin, C. \& G. Anzenberger. 2001. Infant carrying in family groups of Goeldi's Monkeys (Callimico goeldii). American Journal of Primatology, Calgary, 53: 57-67.

Silva JR., E.C. 1981. A preliminary survey of brown howler monkeys (Alouatta fusca) at the Cantareira Reserve (São Paulo, Brazil). Revista Brasileira de Biologia, Rio de Janeiro, 41 (4): 897-909.

Strier, K.B. 2003. Primate behavioral ecology. Boston, Allyn and Bacon, 422p.

TardifF, S.D.; C.V. SANTos; A.J. Baker; L.V. Elsaker; A.T.C. Feistner; D.G. Kleiman; C.R. Ruíz-Miranda; A.C.A. Moura; F.C. Passos; E.C. Price; L.G. Rapaport \& K. Vleeschouwer. 2002. Infant care in lion tamarins, p. 213-232. In: D.G. KLEIMAN \& A.B. Rylands (Eds). Lion tamarins: biology and conservation. Washington, Smithsonian Institution Press, 475p.

Treves, A. 2001. Reproductive consequences of variation in the composition of howler monkey (Alouatta spp.) groups. Behavioral Ecology and Sociobiology, Heidelberg, 50 (1): 6171.

Received in 10.V.2005; accepted in 06.XII.2005. 